\title{
Полезно ли импортировать в Россию «пожизненный наём»?1
}

\begin{abstract}
П.Н. ТЕСля, кандидат экономических наук, Новосибирский государственный технический университет, Новосибирский национальный исследовательский государственный университет, Институт экономики и организации промышленного производства СО РАН, Новосибирск. E-mail: teslia.pavel@gmail.com
\end{abstract}

Аннотация. Статья написана в формате дискуссионного ответа к материалу Ю.П. Воронова «Без расчета на пенсию" в этом же номере. В ней подвергается сомнению предложение автора о частичном внедрении в России системы пожизненного найма, подобной японской. Показано, что работоспособность японской системы опирается на комплементарность ряда социальных институтов, каждый из которых порождает серьезные социально-экономические системные дефекты. В частности, она приводит к усилению эксплуатации работников, особенно молодых и старших возрастов и провоцирует стремление нанимателя к досрочному выводу пожилых работников на пенсию, что приводит к ухудшению их экономического положения. Частичное применение пожизненного найма невозможно, что подтверждается опытом США и Европы, где этим термином ошибочно обозначается система бессрочных (перманентных) трудовых контрактов. Проведенный анализ изменений институциональной среды рынков труда в Японии, Европе и США показал, что в Японии пожизненный наем постепенно модифицируется и фактически отмирает. В западных странах перманентные контракты также постепенно отмирают, поскольку смена технологической парадигмы (цифровая трансформация) требует более гибкой структуры рынка труда.

Ключевые слова: пожизненный наем; перманентный контракт; моральный риск; коэффициент удержания; возрастные когорты

Проект внедрения в отечественную практику элементов зарубежной модели «пожизненного найма» (иногда его не вполне синонимично называют перманентным), по замыслу автора обсуждаемой статьи, должен внушить надежду на смягчение негативных последствий от повышения в России пенсионного возраста. Однако, когда речь идет о сложных социально-экономических институтах, каковым, безусловно, является «пожизненный наем», с плодотворностью такого импорта можно поспорить. Если с одного автомобиля снимают детали и используют их для ремонта другого, это часто срабатывает. Гораздо труднее делать пересадки органов из одного живого организма в другой. И практически невозможно без серьезных революционных потрясений перенести

\footnotetext{
${ }^{1}$ Работа выполнена в рамках проекта XI.170.1.1. (0325-2019-0007) «Инновационные и экологические аспекты структурной трансформации российской экономики в условиях новой геополитической реальности» плана НИР ИЭОПП СО РАН 2019 г. Номер госрегистрации АААА-А17-117022250127-8.
} 
из страны в страну копию большого и сложного института, каким является система пожизненного найма.

Надо сказать, уважаемый автор не отрицает, что японский «фрукт» не без червоточины и к тому же с органическими дефектами, а «введение полномасштабного пожизненного найма в России в настоящее время не имеет перспектив». Поэтому основной мотив обсуждаемой статьи состоит в продвижении идеи благотворности внедрения отдельных элементов перманентной занятости. Мы утверждаем, что вычленять из этой модели какието элементы и объявлять их «пожизненным наймом» как минимум не корректно - вне единого целого они не будут работать.

Рассмотрим пожизненный наем как системное явление, уделив основное внимание его минусам, препятствующим его приживлению в другой среде. Поскольку существует он только в Японии, и, с сильными модификациями, в Южной Кореe, pacсмотрим японский материал, в том числе - в контексте пенсионных проблем. Проанализируем также ситуацию с перманентными контрактами в Европе и в США.

\section{Пожизненный наем, когда он начинается и когда заканчивается?}

Главной особенностью истинного пожизненного найма является то, что прием на работу по соответствующему контракту происходит не в конце и не в середине трудовой карьеры, а в самом ее начале. Почетные профессорские позиции, обозначаемые в некоторых зарубежных университетах термином tenure ${ }^{2}$, о чем пишет наш автор, часто называют разновидностью такого контракта, но это ошибочная трактовка. Тенурному профессору

\footnotetext{
2 Заметим, что tenure в переводе на русский язык означает не только «владение», но и «стаж»- количество проработанных лет, полных и не полных. Система Tenure придумана в качестве альтернативы традиционному краткосрочному найму и широко применяется только в США. Срок стандартного контракта в американских университетах установлен на уровне 3 лет. Если кто-то продержится на одном месте больше 5 лет, он автоматически приобретает статус «тенурного профессора», и управлять таким сотрудником становится намного труднее. Поэтому чтобы профессора не расслаблялись и работали более интенсивно, их (за редкими исключениями) стараются уволить по истечении 3-летнего периода работы. И это не случайно. Многие тенурные профессора со временем перестают генерировать интересные идеи, и их должность превращается в синекуру. Введение модели «пожизненного найма» в российских университетах, предложенная Ю. П. Вороновым, может узаконить и без того не бодрую научную жизнь, особенно в периферийных вузах.
} 
не гарантируется его место до окончания его дней или до того, как он сам решит, что ему пора на покой. Тенура - это всего лишь освобождение от периодического составления отчетов о научных достижениях и от поиска нового места после истечения срока контракта, если бы отчет оказался неудовлетворительным. Даже тенурный профессор при наступлении пенсионного возраста уходит в отставку, освобождая вакансию. На автора данных строк в свое время произвело сильное впечатление увольнение из Роттердамского университета первого нобелевского лауреата по экономике Яна Тинбергена, получившего премию совместно с Рагнаром Фришем (1969 г.). Он ушел «на покой», когда наступил его пенсионный возраст. Заметим, что Я. Тинберген прожил 101 год, довольно долго продолжая трудиться как ученый и после выхода в отставку.

Иногда «пожизненным» называют трудоустройство госчиновников, отдельных работников госструктур (в том числе рабочих казенных предприятий), имеющих бессрочный контракт, который может быть заключен и в середине, и даже в конце карьеры (в отличие от классической японской модели). Однако гарантия длительной занятости у таких работников условна и не распространяется на случаи, например, сокращения штатов. Выход на пенсию также происходит в соответствующий срок, установленный законом. То есть «пожизненным» в буквальном значении этого слова такой контракт не является.

Более того, в Японии те, кого принято называть истинными «пожизненно занятыми», тоже, как правило, отправляются на пенсию сразу по достижении соответствующего возраста (а иногда даже раньше). Реальной «пожизненности» в системе «пожизненного найма» нет.

До недавнего времени японские наниматели не могли увольнять пожизненно нанятых без нарушения закона, однако добровольный досрочный выход на пенсию приветствовался. В условиях патернализма восточного типа добиться этого от сотрудника не так уж сложно. Поэтому «пожизненно нанятые» работники зачастую шли навстречу пожеланиям нанимателя и сами уходили в отставку. При этом нередко многие из них подписывали в той же компании срочный трудовой контракт, либо переходили на неполный рабочий день. Некоторые устраивались в другие фирмы через посредство «диспетчерских» трудовых агентств 
(Dispatched Work Agencies). Работа «под зонтиками» таких агентств почетной не является. К их услугам прибегают те, кто готов работать временно, и там, куда пошлют диспетчеры. Масштабы этого сегмента рынка труда были настолько велики, что в середине 1980-х годов в Японии была создана разветвленная система законов и правил такого диспетчирования.

В последнее время срок обязательного выхода японцев на пенсию соблюдается более строго. Хотя пожизненно нанятых по-прежнему нельзя уволить против их желания без серьезных последствий для работодателя, при наступлении пенсионного возраста пожизненный контракт автоматически прекращается.

Таким образом, фактически происходит ложная интерпретация этого термина. Истина же в том, что пожизненно нанятые - это те, кто работает под защитой закона, запрещающего нанимателям увольнять их до наступления законного срока выхода на пенсию. Далее, чтобы избежать двусмысленности, будем по возможности называть их перманентно занятыми.

\section{Сколько японцев имеют перманентный контракт и как долго в Японии трудятся?}

Рассмотрим, каковы масштабы и тенденции изменения перманентной занятости в Японии, воспользовавшись официальной статистикой ${ }^{3}$ (рис. 1).

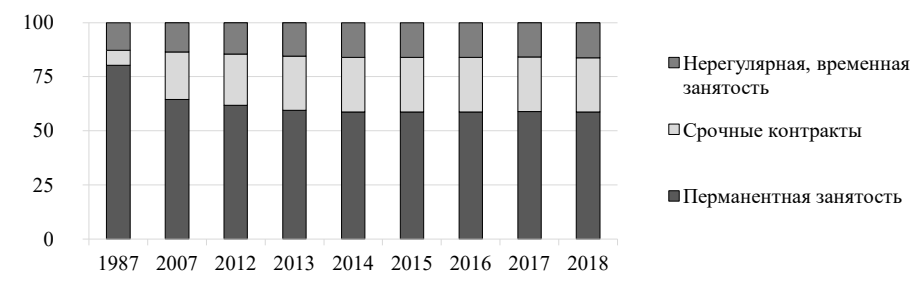

Puc. 1. Структура рабочей силы в Японии по формам занятости в 1987-2018 гг.,\%

Как видно по рисунку, доля перманентной занятости в Японии после 1987 г. к настоящему времени сократилась более чем на 20 п.п. и в последнее десятилетие стабилизировалась на уровне чуть менее $60 \%$. Конец 1980-х годов был переломным

${ }^{3}$ Portal Sight of Official Statistics of Japan. [Эл. pecypc] URL: https://www.e-stat.go.jp/ en/stat-search/ 
периодом, когда страна резко приостановила свой экономический рост. Легко заметить, что работники меняли статус перманентно занятых в основном на занятость со срочными контрактами. Доля низшей, наименее социально защищенной группы людей с нерегулярной и временной занятостью в численности рабочей силы оставалась в течение 30 лет стабильной в пределах 12-16\%. Существовавшее классовое расслоение, таким образом, не изменилось, но и не привело к пауперизации общества.

Тем не менее правительство Японии обеспокоено укоренившимися различиями между статусами перманентных и нерегулярно занятых работников и надеется ликвидировать этот разрыв путем поощрения компаний к принятию более гибких систем организации труда. Уже сейчас несколько компаний предлагают временным работникам постоянные должности, привязанные к конкретным рабочим местам, позволяя сотрудникам пользоваться непрерывностью и безопасностью работы, избегая при этом болезненной ротации и применения к ним других жестких режимов труда; последнее было характерно для большинства временных работников ${ }^{4}$.

В 2015 г. парламент Японии принял закон, согласно которому, трехлетний срок контракта должен применяться только при назначении работника на конкретное рабочее место или в определенное структурное подразделение. По истечении этого срока, если работника не перевели на другое место, кадровое агентство обязано принять меры для обеспечения его приема на перманентную занятость. Фактически на него возлагаются функции трудовой инспекции.

Этот же закон предписывает перевод на статус перманентных работников всех, кто проработал по срочному контракту в одной компании не менее пяти лет [Genda, 2015]. Фактически это означает, что со временем все японцы могут стать «пожизненно

\footnotetext{
${ }^{4}$ Примечательно, что и к перманентно нанятым тоже применяют режим ротации, но такая практика не считается обидной и несправедливой. Более того, пропустив работника через запланированный круговорот смены рабочих мест, его приготовят к безболезненному карьерному росту. Опытный руководитель более умело управляет коллективом. Таким образом, ротация в условиях японского общества амбивалентна. Если ротации и перемене мест подвергается временный работник-это унизительно, а если перманентного работника перемещают с одного места на другое, это хорошо, т.к. его готовят к повышению. Реформа трудового законодательства будет эту амбивалентность устранять.
} 
занятыми». Вряд ли этот формальный механизм будет работать неукоснительно, но размывание концепции «пожизненного найма» произойдет наверняка.

Другим важным направлением трудовой политики в Японии является трудоустройство пожилых работников. Трудоспособное население этой страны, определяемое как «лица в возрасте 15 лет и старше», в настоящее время составляет 110 млн чел., а 32 млн из них старше 65 лет (официальный возраст выхода на пенсию). Учитывая прогнозируемое сокращение численности населения младших возрастных когорт, в предстоящие годы Япония столкнется с проблемой хронической нехватки рабочей силы, если она не сможет задействовать свои недоиспользуемые трудовые ресурсы $^{5}$. Помимо расширения возможностей для женщин, это означает создание правовых и социальных условий, в которых пожилые люди могут продолжать работать до тех пор, пока они желают, и в той мере, в какой способны. Демографические параметры способствуют этому. Средняя продолжительность жизни в Японии составляет 84,6 года.

На рисунке 2 прослеживаются изменения в уровне занятости среди лиц в возрастных группах 60-64 и 65-69 лет в период с 1968 г. по настоящее время. В 1960-е гг., когда значительная часть рабочей силы была занята в сельском и лесном хозяйстве и рыболовстве, уровень занятости для японцев, находящихся за пределами пенсионного возраста (тогда это было 60 лет), превышал 60\%. В условиях быстрого экономического подъема, когда структура промышленности быстро менялась, очень многие японцы находили работу и после выхода на пенсию, но одновременно с этим в большинстве компаний стимулировали досрочный выход на пенсию уже в 55 лет, а итоговый уровень занятости среди пожилых граждан снижался. Положение изменилось в конце 1980-х гг., когда Япония пережила структурный кризис, от которого не смогла оправиться до сих пор.

В 1986 г. парламент принял закон, поощряющий компании выводить работников на пенсию в возрасте до 60 лет, и это способствовало увеличению занятости пожилых людей в начале 1990-х гг. Инерция снижения занятости в пожилых возрастах

\footnotetext{
${ }^{5}$ Нехватка рабочей силы в данном случае должна трактоваться как недостаточное количество плательщиков в пенсионную систему.
} 
некоторое время продолжалась, и к 2004 г. трудился лишь один из трех человек в возрасте 65-69 лет.

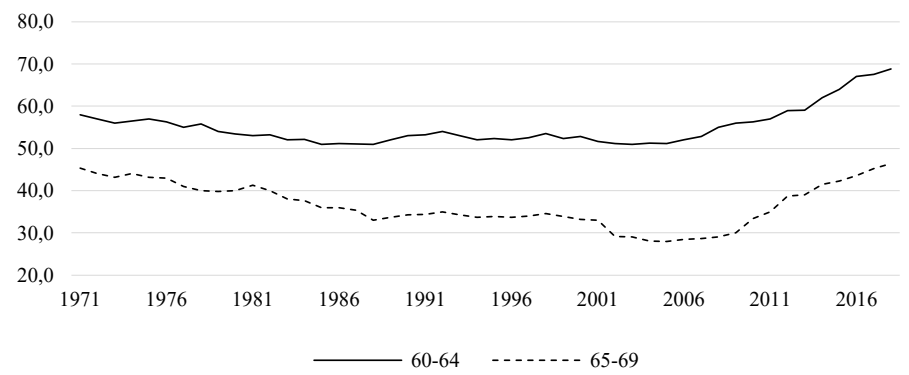

Источник: рассчитано по данным официального сайта японской статистики.

Puc. 2. Доля работающих японцев в возрастных когортах 60-64 и 65-69 лет, \%

В последующие годы японское правительство приняло меры к поэтапному увеличению минимального возраста для получения пенсий с 60 до 65 лет (в 2015 г. переход закончился), а в настоящее время активно обсуждается его повышение до 70 лет (с переходом к 2030 г.).

С 2012 г. работодатели были юридически обязаны предлагать варианты продолжения работы после 65-летнего возраста постоянным сотрудникам, если они захотят продолжать работать. К 2013 г. доля занятых в возрасте 60-64 лет вернулась на уровень, существовавший в начале 1960-х годов. В 2018 г. работало почти 70\% 60-64-летних и 46\% 65-69-летних ${ }^{6}$. Можно ожидать, что в этой возрастной когорте тенденция к повышению занятости сохранится, особенно если будет принят закон о 70-летнем пенсионном возрасте.

\footnotetext{
6 Заметим, что в настоящее время значительное количество японцев (30\%) уходят на пенсию раньше установленного пенсионного возраста 65 лет. Большая часть из них женщины. «Пожизненный наем» выталкивал людей на пенсию до срока, и найти перманентную занятость таким людям почти никогда не удается. Еще интереснее, что аномально много людей, по меркам России, работает в Японии, уже после выхода на пенсию. По данным ПФР, в России на конец 2018 г. работала только четверть получателей страховой пенсии (URL: https:/www.dp.ru/a/2018/11/12/PFR_podschital_ kolichestvo). Это объясняется не только тем, что японцы долго живут и сохраняют здоровье и работоспособность. Очень многим из них не хватает пенсии, хотя ее средний размер от 600 до 1500 долл. в месяц. Японская пенсионная система очень гибка. Вот что заслуживает имитации, а не «пожизненный наем»!
} 
Как видим, проблема пенсионного возраста в условиях системы пожизненного найма действительно выглядит совершенно иначе, чем то, что мы наблюдаем в современной России. Специфические японские трудовые отношения побуждают пожилых людей охотно идти на работу по достижении пенсионного возраста и трудиться на совершенно иных условиях, нежели те, которые действовали в условиях стандартного перманентного контракта.

\section{Пожизненный наем, его структура и связи с другими институтами}

Может ли существовать пожизненный наем вне сочетания с альтернативными формами занятости? Нам представляется, что нет. Более того, принятие сотрудников на длительные сроки без возможности уволить их даже при возникновении форс-мажорных обстоятельств (и порой это дорого обходится компаниям) неразрывно связано со специальными механизмами карьерного продвижения и особых, нерыночных процедур оплаты труда. Распутать этот клубок отношений без разрушения принципа перманентного контракта, по-видимому, невозможно.

Четырьмя столпами послевоенной системы организации рынка труда в Японии были пожизненная занятость, система назначения заработной платы за выслугу лет, система бонусов и профсоюзы предприятий.

Между претендентами, выходящими на рынок труда, существует острая конкуренция за перманентные контракты с крупными корпорациями, кадровую стратегию которых пытаются имитировать также средние и мелкие компании, стремящиеся удержать наиболее ценных сотрудников. При этом есть огромная дифференциация по оплате и условиям труда между перманентно занятыми и нанятыми по срочным контрактам и на неполный рабочий день. Разные категории работников могут трудиться вместе в одной и той же компании и даже выполнять одну и ту же работу, но условия их труда могут быть очень разными. Перманентно нанятые получают регулярные бонусы, пользуются корпоративными социальными программами и т.д. Крупные компании могут предложить эти привилегированные условия работникам компаний-подрядчиков или покупателей, которые не так щедры на условия найма. Практика переманивания чужих рабочих широко распространена, она уживается со встречной 
временной или постоянной передачей своих работников в компании-партнеры.

История взлета популярности системы перманентных контрактов в Японии восходит к послевоенным годам. В 1950-1960-е гг. большинство молодых людей из сельских районов Японии не могли себе позволить даже среднее образование и отправлялись в большие города в поисках работы. Работодатели, со своей стороны, были заинтересованы в приеме молодых и неприхотливых сельчан, привыкших к тяжелому труду и низкому уровню жизни. Последние получили название «золотые яйца» (кин но томаго).

Придя на работу в статусе перманентного работника, молодой человек проходил профессиональную подготовку и год от года поднимался по карьерной лестнице почти независимо от трудовых достижений. При этом росла и его зарплата. По мере развития системы среднего и высшего образования в стране в системе пожизненного найма изменений происходило удивительно мало. Даже поступающие в компанию выпускники университетов прежде чем получить пост инженера или линейного менеджера, по-прежнему проходят профподготовку. Многие индустриальные гиганты даже учредили свои корпоративные университеты для адаптации поступающей молодежи с университетскими дипломами ${ }^{7}$.

Вплоть до середины 1990-х годов молодые люди, нанятые крупной компанией, могли рассчитывать на то, что вся их трудовая деятельность будет связана с ней. Это было справедливо как для трудящихся рабочих специальностей, окончивших техникум или среднюю школу, так и для «белых воротничков»выпускников колледжей. До принятия в 1968 г. закона о равных возможностях в области занятости женщины могли рассчитывать на гарантированную занятость лишь до момента замужества.

До сих пор по традиции перманентные контракты подписываются раз в году - в апреле, и, как правило, только с теми, кто впервые попал на рынок труда. Те, кто не смог устроиться на постоянную работу сразу после окончания учебы, либо по той

\footnotetext{
${ }^{7}$ Интересно отметить стиль учебы и жизни японских студентов (это характерно и для Южной Кореи). Пройдя «ад» вступительных экзаменов, к которым они изнурительно готовятся практически с первого класса школы, студенты довольно сильно расслабляются. Корпоративные университеты компенсируют этот неприятный социальный дефект.
} 
или иной причине потерял работу, попадают на вторичный рынок, который дает мало шансов на получение высоко ценимых постоянных должностей в крупных фирмах.

Обычно японские студенты определяются со своим будущим местом работы задолго до окончания вуза. Они участвуют в семинарах по трудоустройству, проводимых компаниями, общаются с выпускниками своей альма-матер, которые уже работают в желаемой компании. Работодатели нередко и сами наделяют своих молодых сотрудников обязанностями рекрутеров, с целью поиска талантливых выпускников. Эти ранние мероприятия по найму называются «аота гаи» (покупка зеленого рисового поля). Одно время эта практика приняла такой размах, что японское правительство было вынуждено в 1952 г. законодательно установить даты начала посещения компаний, отбора кандидатов и предложения должностей. Соответствующие нормы были отменены только в 1997 г. в связи с изменением экономических условий и глобализацией. Зато вслед за западными компаниями некоторые японские фирмы в последние годы внедрили систему стажировок для студентов магистратуры ${ }^{8}$.

После войны около $20 \%$ выпускников средней школы в Японии сразу шли на рынок труда. По мере развития специального профобразования эта доля неуклонно сокращалась, но до сих пор японские компании часть своих постоянных мест в производственных подразделениях и офисах предлагают выпускникам школ. Взаимодействие компаний со школами хорошо отлажено. Первые ежегодно направляют уведомления о количестве вакансий, вторые рекомендуют на них своих лучших выпускников. Поскольку эти рекомендации составляются на основе успехов в учебе и поведении, у школьников имеется сильный стимул для прилежности в классах и дома.

Система оплаты труда на основе трудового стажа (нэнко дзорецу) идет рука об руку с пожизненной занятостью. Вместо того, чтобы платить за количество и качество труда, компании ставят зарплату постоянных сотрудников в зависимость

\footnotetext{
${ }^{8}$ В России, кстати, эта неоднозначная практика также получила распространение. На качестве получаемого образования она сказывается весьма негативно, это может подтвердить любой вузовский преподаватель. Беда России в том, что корпоративных университетов у нее нет, и некому восполнить пробел знаний, упущенных в годы магистратуры.
} 
от трудового стажа. Новичкам назначается стандартная базовая зарплата, которая затем повышается по мере «выслуги лет». Это дает сотрудникам сильный стимул оставаться у своего первого работодателя, не позволяя менять работу без потери дохода. Такая система недооценивает молодых работников, но хорошо вознаграждает их в последующие годы, даже при снижении производительности. Однако по той же причине компаниям становится невыгодно держать престарелых сотрудников, и их обычно понуждают «добровольно» выйти на пенсию на 3-7 лет раньше официального пенсионного возраста. После этого они могут быть повторно наняты той же фирмой по краткосрочным контрактам или устроиться на неполный рабочий день, вплоть до окончательного ухода на пенсию. Разумеется, при этом уменьшаются и зарплата, и социальный пакет. Таким образом, система пожизненного найма приводит к специфической дискриминации пожилых сотрудников.

Бонусная система еще одна неотъемлемая часть модели перманентной занятости в Японии. Штатные работники получают фиксированную базовую зарплату, которая зависит от квалификации и стажа работы в компании. Ее, как правило, достаточно для покрытия текущих расходов, а для крупных покупок и сбережений используются бонусные выплаты, осуществляемые дважды в год (в июне и декабре). Это значительные суммы, равные окладу за один-три месяца. Хотя термин «бонус» в обычном понимании предполагает специальное вознаграждение за хорошую работу, в Японии полугодовая премия стала неотъемлемой частью системы оплаты труда. Размер бонуса зависит от финансового результата за соответствующий период и является предметом коллективных переговоров между руководителями и профсоюзом, в этом смысле его можно считать формой участия в прибыли. Однако даже те компании, которым угрожает банкротство, продолжают выплачивать полугодовые бонусы, хотя бы и сниженные. Поскольку работодатели и работники рассматривают бонусы как часть пакета оплаты труда, они фактически выплачиваются из накопительного фонда, который формируется за счет удержаний из ежемесячной заработной платы. Такая система, будучи предсказуемой и значимой, способствует бережливости и рациональному планированию расходов, но вряд ли способна стимулировать трудовой энтузиазм. 
Новые отношения, возникшие в 1950-х годах между работниками и руководством компаний, сформировали концепцию фирменных профсоюзов. Это объединение работников конкретной компании, в которое входят все ее штатные сотрудники, не являющиеся руководителями, независимо от выполняемой ими работы (рабочие, технические, офисные специальности и т.д.). Профсоюзы (как правило, в полном согласии с руководством компаний) обеспечивают своим членам надежные гарантии занятости и хорошую заработную плату и льготы. При этом временные сотрудники (работающие по срочным контрактам или неполный рабочий день), которым вход в эти организации заказан, служат неким демпфером в ситуации возможных конфликтов. Профсоюзы никак не препятствуют работодателям нанимать/увольнять их в случае надобности. Таким образом совместными усилиям профсоюзы и руководство компаний добиваются повышения эффективности производства. Так, после «нефтяного шока» 1973 г. традиционные рабочие места «синих воротничков» активно заполнялись не состоящими в профсоюзе контрактниками и работниками описанных выше подрядных диспетчерских фирм. В результате доля членов профсоюзов, как и доля перманентно занятых, сократилась, хотя общее число работников оставалось довольно стабильным.

\section{Дискриминация в системе пожизненного найма}

Из вышесказанного следует, что все группы работников, которые не вошли в состав нанятых на перманентной основе, подвергаются дискриминации. Им платят меньше, их ставят на более тяжелую, монотонную работу, их увольняют, когда требуется «сбросить балласт» в трудные времена. Фактически система трудовой дискриминации составляет социальную финансовую базу системы «пожизненного найма», защищая штат основного персонала от колебаний рыночной конъюнктуры.

Следует отметить наличие дискриминации и среди перманентно нанятых. Младшим по стажу недоплачивают, их в порядке ротации переводят с одного места на другое, иногда даже с необходимостью переезда. И делается все это достаточно бесцеремонно - мнение сотрудников ничего не значит.

Дискриминация затрагивает сферу чувствительного для самолюбия квалифицированных работников восприятия значимости квалификации, образования, опыта, эрудиции и других качеств 
специалиста. Продвижение по принципу «чем выше стаж, тем выше должность» регулярно приводит к тому, что на руководящих должностях оказываются люди менее квалифицированные, чем те, которыми они руководят. Подчиненные испытывают фрустрацию и отчуждение. Кроме того, сами приказы некомпетентных руководителей зачастую оказываются ошибочными, их нередко саботируют. Это не может не сказываться на эффективности бизнеса.

Нельзя сказать, что в японских корпорациях этого не учитывают. Однако борьба с корпоративными кадровыми перекосами порождает другие проблемы. Назовем лишь две из них, достаточно казусные. Во-первых, это бюрократизация. Большинство важных решений в японских корпорациях принимаются по принципу консенсуса. Это страхует от многих ошибок, но вместе с тем и удлиняет процесс согласования, влечет потери времени и, самое главное, часто блокирует оригинальные творческие идеи. Во-вторых, для формирования корпоративного духа, создания атмосферы непринужденности, товарищества и чувства локтя руководители часто организуют для подчиненных (обычно по пятницам, а то и чаще) посещение культурных, спортивных, а по большей части - злачных мест. Отказ от участия в корпоративной попойке этически неприемлем, что для некоторых сотрудников оборачивается серьезными проблемами со здоровьем. Этот казус весьма характерен для системы социальных отношений пожизненного найма.

Дискриминация женщин в корпорациях с «пожизненным наймом»- наиболее тяжелая форма дискриминации.

Многие крупные японские компании практикуют две кадровые системы для женщин, вновь нанятых по перманентному контракту: некарьерную модель найма (иппаншоку) и карьерную (сегосхоку). Женщины иппаншоку работают только помощниками, и их шансы на продвижение ограничены. Женщины сегосхоку рассматриваются как профессионалы и имеют такие же шансы на продвижение по службе, как и их коллеги-мужчины. Как правило, компании еще до подписания контракта требуют от женщин взятия определенных обязательств, что ограничивает количество доступных для них карьерных позиций. При этом практически все мужчины работают на карьерных должностях. В 2003 г. Конвенция ООН о ликвидации всех форм дискриминации в отношении 
женщин 9 признала систему иппаншоку/сегосхоку «косвенной дискриминацией» и призвала правительство Японии принять меры по ее искоренению. С увеличением числа работающих женщин растет и количество женщин-сегосхоку, в том числе - на руководящих должностях, однако возможности продвижения по службе для них по-прежнему ограниченны. Кроме того, даже в тех корпорациях, где отказались от системы иппаншоку/сегосхоку, как правило, отмечается значительный гендерный разрыв в доходах через несколько лет после приема специалиста на работу.

Еще одно проявление половой дискриминации - более ранний «пенсионный возраст» для женщин. До недавнего времени многие компании требовали, чтобы женщины выходили на пенсию сразу после замужества, что поддерживалось исторической традицией вопреки официальному законодательству. Еще в 1966 г. Токийский окружной суд постановил, что женщина не может быть уволена только потому, что она вышла замуж. Тремя годами спустя этот же суд вынес решение против компании, которая установила возраст выхода на пенсию 55 лет для мужчин и 30 - для женщин. Однако несмотря на то, что японские женщины добились признания незаконным принуждения к раннему выходу на пенсию в связи с замужеством, на деле многие из них добровольно оставляют работу, чтобы посвятить себя детям и семье. Коэффициент участия в рабочей силе показывает, как меняется участие женщин в трудовой деятельности в зависимости от возраста. Уровень показателя высок, когда им 20 лет, становится ниже в 30 лет, когда они вступают в стадию воспитания детей, и увеличивается после 40 лет, когда дети становятся самостоятельными.

Одним из наиболее популярных видов трудовой деятельности у японок является преподавание/педагогика. В системе дошкольного образования доля женщин превышает 90\%, среди учителей начальной школы - более $60 \%$, среди преподавателей колледжей и университетов - 20\% (в основном это преподаватели женских и младших колледжей). Женщины заняты в профессиях, связанных с социальным обеспечением (уход за инвалидами и пожилыми людьми, помощники по дому и т.д.), сферой услуг, играют важную

\footnotetext{
${ }^{9}$ Конвенция о ликвидации всех форм дискриминации в отношении женщин, принята резолюцией 34/180 Генеральной Ассамблеи ООН от 18 декабря 1979 года. [Эл. ресурс] URL: https://www.un.org/ru/documents/decl_conv/conventions/cedaw.shtml
} 
роль в медицине. Хотя они составляют лишь 10-20\% врачей и техников, нижние ступени в основном заняты женщинами. Более $60 \%$ фармацевтов в Японии - женщины [The Japanese Employment...].

\section{Пожизненный наем в Европе и США}

В Европе и США перманентные контракты были известны давно, но массово стали применяться с середины 1970-х гг., когда в надежде на создание благоприятной корпоративной культуры, повышающей лояльность персонала, стали активно перениматься японские управленческие модели. В Европе и США надеялись, что это даст импульс развитию, оживит экономическую активность, подобно тому, как это происходит с человеческим организмом в результате переливания крови. Надежды не оправдались, особенно в Европе.

Поскольку пойти на полномасштабную имитацию японской модели рынка труда с пожизненным наймом ни в Европе, ни в США не решились, частичное, однобокое заимствование перманентных контрактов пользы не принесло. Гармонизация европейского трудового законодательства проходила по пути усиления защиты трудящихся. Процедуру увольнения сотрудников обставили целым набором обязательных условий (например, работодатель не просто должен выплатить увольняемым солидную компенсацию, но и предпринять все возможные усилия для их нового трудоустройства).

Как это часто бывает, при движении по пути к благой цели, достигли обратного результата: видя, что увольнение персонала может обернуться огромными издержками, предприятия стали набирать новых сотрудников на бессрочные контракты только в случае крайней необходимости. Сильнее всех пострадала молодежь, которой стало очень трудно найти постоянную работу. Особенно - во Франции, Испании, Италии. Статистика безработицы в Испании показывает, что в 2018-2019 гг. в эту категорию попали 25,6\% от количества работоспособных граждан, из них $34,4 \%$ - молодые люди до 25 лет. Усугубляет безработицу постоянный приток иммигрантов, пользующихся определёнными социальными льготами ${ }^{10}$.

\footnotetext{
10 Эл. pecypc URL: https://visasam.ru/emigration/rabota/bezrabotica-v-ispanii.html (дата обращения: 20.05.2019).
} 
Сегодня перманентная занятость в западных странах перестала быть привлекательным образцом. Помимо прочего, она плохо

\section{уживается с технологическим прогрессом.}

В современной Европе процессы углубления капитала (увеличения капиталоемкости производства, автоматизации, роботизации) приводят к росту спроса на работников с низким образованием и квалификацией, «приставленных» к роботам и автоматам. Одновременно с этим сегодня для обслуживания высокотехнологичного физического капитала (наладки, ремонта, модернизации) требуется более образованная и квалифицированная рабочая сила. Таким образом, углубление капитала приводит к расслоению и деградации значительной части рабочей силы.

В странах EC на национальном и межгосударственном уровнях (Европейской комиссии) принимаются меры по содействию внедрению автоматизированных производств, искусственного интеллекта в частном и государственном секторах [Employment.., 2018]. Франция объявила об инвестировании 1,5 млрд евро в искусственный интеллект в течение ближайших пяти лет. Важной тенденцией, появлению которой в значительной степени способствовало распространение новых технологий, сегодня стало увеличение числа работников, состоящих в нестандартных (нетипичных) отношениях с работодателями. Одновременно наблюдается сокращение числа постоянных работников и рост количества «свободных предпринимателей», фрилансеров и т.д.

Можно предположить, что в будущем перманентная занятость станет еще менее значимой для нанимателей. Причина в том, что уменьшение численности постоянных работников будет способствовать усилению гибкости при проведении технологической политики. Разумеется, это вызовет новые проблемы. Нестандартные трудовые контракты наверняка снизят удовлетворенность от трудовой деятельности, негативно скажутся на социальной защищенности, финансовом благополучии работников. Серьезной проблемой является тот факт, что современное социальное страхование в большинстве стран Европы привязано к модели перманентного (долгосрочного) найма.

Перманентная занятость в течение полного рабочего дня сегодня все еще превалирует в Европе (около 60\% трудовых 
контрактов). Однако рост числа нестандартных форм найма ведет к структурным сдвигам. Так, за 2002-2016 гг. доля перманентных контрактов сократилась с 62 до 58\% (рис. 3). Самозанятость без привлечения работников стала более массовой, увеличилась распространенность срочных контрактов, как на полный, так и на неполный день. Особенно сильно эти изменения затронули молодых работников.

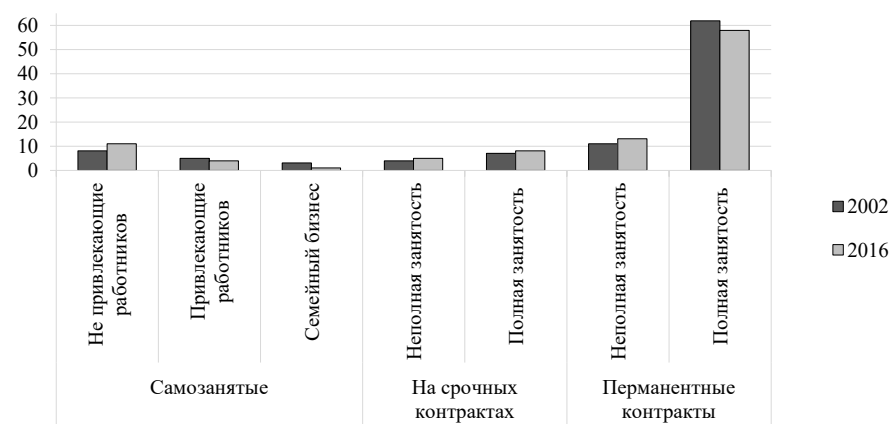

Источник: рассчитано по данным Евростата. URL: https://ec.europa.eu/eurostat/ statistics-explained/index.php/Labour_market_and_Labour_force_survey_(LFS)_ statistics

\section{Puc. 3. Структура занятости в Европейском союзе (28 стран) по видам и срочности, $\%$}

Технический прогресс и цифровизация привели к новым возможностям рынка труда с точки зрения автономии, гибкости, условий охраны здоровья и безопасности. Однако последовавшие структурные изменения негативно сказались на условиях труда и качестве жизни большого количества работников, особенно из числа временных. Более того, возникли новые профессии и виды деятельности, которые вообще не предполагают полной занятости.

Сегодня самозанятость составляет $11 \%$ от общей занятости в ЕС, и существует реальная возможность того, что она будет расти по мере развития платформенных моделей организации труда. Это создаст серьезные проблемы, например, в обеспечении справедливых условий труда и адаптации систем социальной защиты [Pesole et al., 2017]. Отдельная проблема - обеспечение инклюзивного образования и профессиональной подготовки для 
инвалидов, с тем, чтобы они могли воспользоваться потенциальными преимуществами новых форм работы.

Обращает на себя внимание тот факт, что и в Европе, и в Японии перманентные контракты заключены с примерно 2/3 работников. Однако близость этих цифр не должна обманывать: пожизненного найма в японском стиле в Европе нет. Еще менее на японскую модель похожа структура трудовых отношений в США [Farber, 2007].

\section{Устойчивость системы пожизненного найма}

Пожизненный наем очень часто не гарантирует трудоустройство даже до официально принятого в стране пенсионного возраста. Даже если в контракте записано, что наниматель примет все меры к сохранению за сотрудником рабочего места, существуют обстоятельства непреодолимой силы, например, банкротство компании. Наконец, сами работники могут счесть дальнейшую работу в компании не интересной или малоперспективной или у них возникнут личные (семейные) обстоятельства, вынуждающие их покинуть свое место работы, что приводит к потере перманентной занятости. Поэтому любая статистика по доле пожизненно (перманентно) занятых на самом деле обманчива. Так, в литературе нередко встречается утверждение, что настоящих «пожизненно нанятых» в Японии примерно треть от всех работников, что почти вдвое ниже официальной статистики.

Альтернативным относительно официальной статистики вариантом оценки является проведение глубинных выборочных обследований и опросов. Такие работы проводились в Японии и США, и их результаты отражены в литературе. В 1985 г. М. Хашимото и Дж. Раисян опубликовали масштабное исследование состояния и динамики рынков труда в Японии и США. Авторы изучали, на каких местах окажутся члены исследуемых групп работников с интервалом в десять лет. Если место работы не изменилось, работу можно считать, скорее, постоянной, в противном случае - работа не постоянна. Такая постановка представляется нам довольно корректной при сопоставлении существенно различающихся социальноэкономических систем. Отметим и то, что Россия гораздо 
ближе по менталитету, да и по институциональному устройству к США, чем к Японии.

По итогам исследования авторы пришли к выводу, что в Японии длительность удержания работы примерно в полтора раза превосходит аналогичный показатель в США, а зарплата японских работников более тесно привязана к стажу, чем у американцев. В Японии прекращение найма у постоянно нанятых происходило в большинстве случаев до достижения официального пенсионного возраста (в изучаемый период -60 лет). При этом японские компании перечисляли увольняемым разовые выплаты, величина которых не превышала приведенной (дисконтированной) стоимости дифференциала между японской и американской пенсиями [Hashimoto, Raisian, 1985].

Главный вывод исследования заключался в том, что глубинная статистика японского рынка труда подтверждает серьезную озабоченность японских компаний длительным удержанием своих работников, и одновременно - отсутствие у них заинтересованности держать их до наступления пенсионного возраста. Еще одно любопытное наблюдение - важным инструментом формирования ядра японского «пролетариата» (занятого как физическим, так и умственным трудом) является отсев работников из компаний на ранних этапах их карьеры, часто болезненный и в финансовом и в эмоциональном отношении. Чем больше стаж работы (до определенных пределов), тем более вероятно, что сотрудник останется в компании.

Это пионерное исследование в 1990-х продолжил японский ученый Т. Като. На основе анализа статистических баз данных он показал, что обнаруженные М. Хашимото и Дж. Раисяном свойства японского рынка труда полтора десятилетия спустя остаются в силе. По-прежнему японские компании стремятся обеспечить стабильность персонала, однако коэффициент удержания, определенный как доля работников, продолжавших трудиться на одном месте в течение десяти лет, сократился с $80 \%$ до 70\%. Так сказалось «потерянное десятилетие»-затяжная стагнация национальной экономики, наступившая после финансового кризиса, вызванного крахом рынка недвижимости [Kato, 2001]. Удивительно, что в этих условиях японская система трудовых отношений оказалась настолько устойчивой. Тем более что американский рынок труда в тот же период деградировал, несмотря на гораздо 
более благополучное положение экономики США по сравнению с Японией [Farber, 2007].

Т. Като не ограничился анализом статистики, он провел опрос менеджеров японских компаний. Выяснилось, что реальное положение на японском рынке труда не так благополучно, как это следует из усредненных цифр. Относительная стабильность рабочих мест в целом по экономике достигалась ценой жесткой политики в секторе малых и средних предприятий. Последние в кризисный период интенсивно переводили постоянных работников на срочные контракты и на неполный рабочий день. Особенно пострадали женщины: из них неполный день в 1980 г. трудились $19 \%$, а в 2002 г. - уже $39,7 \%$.

Несмотря на то, что основной удар рыночной стагнации принял малый и средний бизнес, крупные фирмы тоже не избежали потрясений. Там также практиковался переход на неполный рабочий день, но к этому добавился специфический для японских компаний, связанных друг с другом сложной сетью социальных отношений, трансфер работников из крупного предприятия в смежные с ним компании (например, поставляющие для него сырье и материалы или покупающие его продукцию). Многих инженеров-конструкторов переводили в маркетинговые службы.

Некоторым крупным компаниям пришлось уволить часть срочных работников. Почти во всех случаях увольняемые получали компенсационные выплаты, размер которых, как правило, был привязан к их возрасту. Так, в одной из опрошенных корпораций 30-летним выплачивалось пособие в размере 12 месячных средних зарплат, 40-летним - 18, 50-летним - 48, а 57-летним - только за три месяца ${ }^{11}$ [Kato, 2001].

К началу 2010-х «потерянное десятилетие» переросло в двадцатилетие. Т. Като продолжил исследование японского рынка труда совместно с Р. Камбаяши. Выяснилось, что процесс деградации японской системы пожизненного найма

\footnotetext{
${ }^{11}$ Опрошенные рабочие жаловались, что их увольнение наносило урон семейной чести, ведь работали они в знаменитых компаниях. Интересно, что увольняемым с переводом в родственные компании давались обещания, что их вернут на прежнее место, когда времена изменятся к лучшему. Еще интереснее, что отдельным увольняемым работникам некоторое время продолжали выплачивать базовую зарплату (напомним, что кроме нее работникам японских компаний периодически выплачивали бонусы уволенным их не платили).
} 
не остановился. Хотя система в целом продолжает работать, но «работает» она в основном на среднее поколение за счет молодого. Коэффициент удержания рабочих мест в 2002 г. у сотрудников со стажем менее пяти лет заметно сократился относительно предыдущих периодов. Люди со стажем 5-9 лет по-прежнему продолжали работать в течение 10 лет на одном месте с вероятностью $70 \%$. У более старших возрастных когорт изменения были менее определенными [Kambayashi, Kato, 2011]. Тем временем в США, несмотря на относительное экономическое благополучие, продолжали возрастать текучесть кадров и безработица. При этом американцы при увольнении не получали никаких компенсаций или моральной поддержки от бывших работодателей. В общем, это и понятно - у них же не было системы пожизненного найма.

Справедливости ради следует отметить, что веру в стабильность японской системы пожизненного найма разделяют далеко не все эксперты. Так, Кавагучи и Уено, результаты исследования которых опубликованы под эгидой Кабинета министров [Kawaguchi, Ueno, 2011], намного более пессимистичны, чем Като и Камбаяши. Эти авторы, в частности, отмечают, что доля вынужденных расставаний работников и работодателей увеличилась с 10\% в 1990 г. до 20\% в 2000 г. (правда, еще через десять лет она сократилось до 15\%), и такое изменение сроков работы на одном месте происходило вовсе не из-за «счастливых перемещений» (happy job hoppings).

Еще один феномен, характеризующий особенности системы пожизненного найма, проявился в особенно любопытном для нас процессе реформирования японской пенсионной системы. В 1998 г. парламент Японии принял закон об увеличении пенсионного возраста - с 60 до 65 лет - поэтапно, на один год за каждые три календарных года. Не сразу (в 2006 г.), но все же был принят и закон, обязывающий компании предлагать работу тем, у кого наступал пенсионный возраст (или кто готов выйти на пенсию раньше срока), но при этом желает подрабатывать. Добились противоположного: компании делали настолько невыгодные предложения, что никто не хотел их принимать [Yamada, Higo, 2011]. 


\section{Выводы}

Мы подробно рассмотрели особенности системы пожизненного найма, чтобы показать, что она может работать только при наличии особых комплементарных институтов: двойственной структуры экономики (сочетания крупных компаний и родственных им мелких и средних сателлитов); системы оплаты труда, привязанной к стажу; специфической бонусной системы; наличия в структуре трудового рынка дискриминируемых групп и т.д.

Пожизненный наем остро чувствителен к состоянию рыночной конъюнктуры. Даже в Японии, стране с веками культивируемым патернализмом, этот институт постепенно отмирает из-за затянувшейся экономической стагнации. Импорт же чужих управленческих моделей, пусть и хорошо зарекомендовавших себя, даже в период экономической стабильности далеко не всегда приводит к позитивным результатам. В условиях нестабильности, в чужеродной институциональной среде он практически обречен на провал.

Чрезвычайно важно, что пожизненный наем в его японском варианте работает в патерналистской системе взаимного доверия и лояльности, которые чрезвычайно сложно (если вообще возможно) воспроизвести в другой стране. Трудно себе представить, что россияне будут настолько лояльны, чтобы «проглотить» несправедливость компании, выгоняющей на досрочную пенсию стариков, чтобы тут же принять их на более низкую зарплату.

Пример российского перманентного найма в организациях типа РЖД лишь подтверждает этот вывод. Железнодорожники - члены особой касты, которая формировалась в России на протяжении полутора столетий. Войти в нее может далеко не каждый. Эта возможность почти полностью ограничена моментом поступления в один из профильных вузов и колледжей или приема на работу в систему РЖД в молодом возрасте. Примечательно, что связисты и энергетики подобных каст не образуют - во-первых, эти рынки труда не являются столь же монополизированными, как на железной дороге, во-вторых, в этих отраслях используются динамично развивающиеся технологии, так что и предприятия, и отрасли 
в целом находятся в состоянии постоянной организационной и социальной трансформации.

По этим причинам, по глубокому убеждению автора, предложение уважаемого Ю.П. Воронова в России работать не будет.

\section{Литература/References}

Employment and Social Developments in Europe (2018). European Commission Directorate-General for Employment, Social Affairs and Inclusion Directorate A. European Union, 2018.

Farber, H. (2007). Labor Market Adjustment to Globalization: Long-Term Employment in the United States and Japan. Paper presented by the Trans Pacific Labor Seminar. Santa Barbara, CA.

Genda, Y. (2015). Japan's Employment System in Transition. Nippon.com: Available at: https://www.nippon.com/en/currents/d00151/

Hashimoto, M., Raisian, J. (1985). Employment Tenure and Earnings Profiles in Japan and the United States. American Economic Review. Vol. 75 (4). Pp. 721-735.

Kambayashi, R., Kato, T. (2011). Long-term employment and job security over the last twenty-five years: A comparative study of Japan and the US. IZA Discussion Papers, No. 6183, Institute for the Study of Labor (IZA), Bonn. Available at: http:// nbn-resolving.de/urn: nbn: de:101:1-201201103169

Kato, T. (2001). The End of "Lifetime Employment" in Japan? Evidence from National Surveys and Field Research. Columbia Business School Center on Japanese Economy and Business Working Paper Series.

Kawaguchi, D., Ueno, Y. (2011). Declining Long-Term Employment in Japan. Economic and Social Research Institute. Cabinet Office Tokyo, Japan

Pesole, A., Brancati, C.U., Fernández-Macías, E., Biagi, F., González Vázquez, I. (2017). Platform workers in Europe. Evidence from the COLLEEM Survey. JRC, European Commission.

The Japanese Employment System: Available at: http://www.crosscurrents. hawaii.edu/ content.aspx?lang=eng\&site $=$ japan $\&$ theme $=$ work \&subtheme $=$ EMPLO Y\&unit=JWORK022]

Yamada, A., Higo, M. (2011). Institutional barriers to work beyond retirement in an aging Japan: Evidence from a recent employee survey. Contemporary Japan

Статья поступила 16.05.2019.

Для цитирования: Тесля П.Н. Полезно ли импортировать в Россию «пожизненный наем»?// ЭКО. 2019. № 11. C. 132-155. DOI: 10.30680/ECO01317652-2019-11-132-155.

For citation: Teslia, P.N. (2019). Is it Useful to Import "Lifetime Employment" to Russia? ECO. No. 11. Pp. 132-155. (In Russ.). DOI: 10.30680/ECO0131-76522019-11-132-155. 


\section{Summary}

Teslia, P.N., Cand. Sci. (Econ), Novosibirsk State Technical University, Novosibirsk National Research State University, Institute of Economics and Industrial Engineering, SB RAS, Novosibirsk

Is it Useful to Import "Lifetime Employment" to Russia?

Abstract. The article questions the proposal of Yu.P. Voronov on the partial implementation of the system of lifelong employment similar to the Japanese one in the conditions of modern Russia. It is shown that the efficiency of the Japanese system is based on the complementarity of a number of social institutions, each of which generates serious socio-economic systemic defects. Partial implementation of lifelong employment is not possible. This is confirmed by the fact that there is no full-scale application of life-time employment either in the US or in Europe, and this term mistakenly refers to the system of indefinite (permanent) employment contracts. It is considered, how the institutional environment of labor markets in Japan, Europe and the United States is changing. It is shown, specifically, that the lifetime employment system in Japan is gradually being modified and is actually dying out. It is shown also that life-long employment not only does not facilitate the situation for older workers, but also provokes the moral risk for employers - the latters' desire for early retirement of the employees, which leads to an aggravation of the economic situation for older people. Lifetime employment in Japan is being modified to increase the exploitation of workers of all ages, especially the youngest and oldest ones. It is noted that permanent contracts are also gradually dying out, as the change of technological paradigm (digital transformation) requires a more flexible structure of the labor market.

Keywords: lifetime employment; permanent contract; moral hazard; retention rate; age cohorts 